\title{
Izozte-urtze ziklo bidezko mintz-ereduen fusioa
}

\section{(Freeze-thaw mediated model membrane fusion)}

\author{
Bingen G. Monasterio*, Felix M. Goñi \\ Instituto Biofisika (CSIC, UPV/EHU) eta Biokimika \\ eta Biologia Molekularreko Saila (UPV/EHU)
}

\begin{abstract}
LABURPENA: Mintz ereduak, bai zelularen bai zelulako organuluen arkitektura imita dezaketenez, erabilgarriak izan daitezke proteina-lipido elkarrekintzak, geruza bikoitzean txertatutako proteinen egiturak edo mintzen dinamika ikertzeko. Gainera, mintz ereduen diseinu kontrolatu bat egiteko aukera dagoenez, konposizio fisiko-kimiko eta tamaina jakineko egitura lipidikoak sor daitezke. Horrela, bada, mintz eredu hauek izan ditzaketen erabilerak gero eta ugariagoak izaten ari dira; horien artean ditugu, hain zuzen ere, fusio prozesua ikertzeko entseguak. Jakina da zeluletan fusioa oso prozesu garrantzitsua dela; espermatozoideek egiten duten obuluaren ernalketa, exozitosi konstitutibo eta arautua edo organuluen biogenesia, esaterako, fusio prozesuetan oinarritzen dira. Ikerketa honetan, izozte-urtze ziklo bidezko mintz ereduen fusio kontrolatu bat egiteko teknikaren efikazia neurtu da. Tamaina (SUV, LUV eta MLV) eta konposizio molekular ezberdineko (fosfatidilkolina edota fosfatidilkolina, esfingomielina, fosfatidiletanolamina eta kolesterol kantitate ezberdineko) mintz ereduak erabili dira. Fusio maila erresonantzia bidezko energia transferentzia (FRET) izeneko teknikaz neurtu da, horretarako NBD-PE eta Rho-PE markatzaile fluoreszenteak mintz ereduetan txertatuz. Horrela, bada, ikerketa honetan honako hauek ikertu dira: saiakuntza mota hauetan erabili beharko liratekeen mintz eredu eta lipido mota egokienak, markatzaile fluoreszente kantitate eta izozte-urtze ziklo kopuru optimoak, eta fusio osteko egitura lipidikoen morfologia. Azkenik, teknika hau GUV deritzen mintz ereduak sortzeko baliagarria izan daitekeela frogatu da.
\end{abstract}

HITZ GAKOAK: Mintz ereduak, SUV, LUV, MLV, GUV, fusioa, izozte-urtze zikloak, lipidoak.

\begin{abstract}
Model membranes are models that somehow mimic natural biomembranes. They have being widely used for investigating many cell events as protein-lipids interaction, the architecture of proteins embedded in the membranes or the membrane dynamic. In addition, the design of model membranes can be controlled in order to form specific physicochemical composition and size structures. It is known that the fusion process is very important in the cell; the fertilization of an ovule by a sperm, the constitutive and regulated exocytosis and the biogenesis of organelles are some clear examples of this. In the present study, we try to measure the efficacy of a freeze-thawed mediated fusion process. We have used lipid membranes of different sizes (SUV, LUV and MLV) and compositions (phosphatidylcholine or different amounts containing phosphatidylcholine, sphingomyelin, phosphatidylethanolamine or cholesterol). The fusion efficacy has been measured by fluorescence resonance energy transfer (FRET) experiments. NBD-PE and Rho-PE fluorescent probes have been inserted in model membranes for this purpose. We have proved which would be the best type of model membrane, its lipid composition, the fluorescence percentage needed and the required freeze-thawed cycle number to obtain the optimal fusion results. Finally, we have studied the morphology that the lipid structures confer after the fusion process, concluding that this technique can be useful for the synthesis of the GUV called model membranes.
\end{abstract}

KEYWORDS: Model membranes, SUV, LUV, MLV, GUV, fusion, freeze-thawed cycles, lipids.

* Harremanetan jartzeko / Corresponding author: Bingen G. Monasterio, Instituto Biofisika (CSIC, UPV/EHU), Sarriena auzoa z. g., 48940, Leioa, Euskal Herria. - bingen_gm@hotmail.com - https://orcid.org/0000-0002-8714-9427.

Nola aipatu / How to cite: Monasterio, Bingen G.; Goñi, Felix M. (2020). «lzozte-urtze ziklo bidezko mintz-ereduen fusioa»; Ekaia, 37, 2020, 175-188. (https://doi.org/10.1387/ekaia.21109).

Jasoa: 26 iraila, 2019; Onartua: 22 azaroa, 2019.

ISSN 0214-9001 - eISSN 2444-3255 / (c) 2020 UPV/EHU

(c) () (9) Obra hau Creative 


\section{SARRERA}

\subsection{Mintz ereduak: zelula mintzak ikertzeko tresna egokiak}

Bangham eta haren lankideak izan ziren lehen aldiz liposomak mintz eredu gisa erabiltzen hasi zirenak [1]. Ordutik, liposomak oinarritzat hartuz egindako ikerketak era esponentzialean hazi dira. Liposomak, lipidoz osatutako nanometrotako edo mikroitako diametrodun egiturak dira, zeinak lipido bakar batez edo lipido nahaste batez osatuak egon daitezkeen eta geruza bat edo gehiago izan ditzaketen [1]. Gainera, mintzek, lipidoez gain, proteinak eta azukreak ere izan ditzakete txertatuak, zeinek konposizioaren arabera ezaugarri fisiko-kimiko aldakorrak dauzkaten [2]. Haien egonkortasuna eta biomimetismoa dela eta, hobekien ezagutzen diren liposomak, eta gaur egun erabilera biomediko ugarienak dauzkatenak, geruza bakarrekoak dira. Horien artean, 40-60 nm-ko diametrodun SUVak (Small/Sonicated Unilamellar Vesicles), 100-500 nm-ko diametrodun LUVak (Large Unilamellar Vesicles) eta $2 \mu \mathrm{m}$-ko batez besteko diametrodun GUVak (Giant Unilamellar Vesicles) ditugu [3]. Bestalde, hainbat geruzatako mintz ereduei MLV (Multilamellar Vesicles) deritze.

Geruza bakarreko mintz ereduen artean, haien tamainaz gain, badira beste ezberdintasun garrantzitsu batzuk ere. SUVen eta LUVen artean dagoen ezberdintasun nagusia, haien kanpoko eta barneko monogeruzen artean daukaten lipido proportzio ezberdina da. LUVetan banaketa ia simetrikoa da [4], eta SUVek, berriz, erradio txikiak eragindako okerdura dela eta, lipido molekulen \% 60-70 kanpoko geruzan daukate [5]. Horren ondorioz, SUVen kanpoko eta barneko geruzen paketatze maila ezberdina da [6], eta horrek lipidoen mugikortasun eta nahaskortasun ahalmena jaistea eta aldi berean konposizio ezberdineko domeinu lipidikoak egotea eragiten du [7]. Paketatze mailaz gain, bestelako ezberdintasun nabarmen bat barne bolumenarekin lotua dago. Izan ere, SUVen edukiera maiz ez da nahikoa izaten iragazkortasun edo ioi trukeak ikertzeko. Aipatutako arrazoi horiengatik, LUVak egokienak izan ohi dira mintz biologikoen ikerketa biofisikoak egiteko [6].

Mintz ereduek zelularen konplexutasuna sinplifikatuz, zelula baten egitura eta organuluak imitatzea ahalbidetu dezakete. Horien laguntzaz, zelulan gertatzen diren proteina-lipido elkarrekintzak, lipidoen bidezko proteinen erregulazioa, mintzen dinamika, mintzari lotutako proteinen egituraren ezagutza, zeluletan gertatzen diren biomolekula eta molekula txikien askatze sistemak edo fusio prozesuak iker daitezke $[8,9]$.

\subsection{In vivo fusioaren garrantzia}

Mintzen fusioa deitzen zaio hasieran bi geruza independente direnak geruza jarraitu bakarra bihurtzeko prozesuari [6]. Fusioak garrantzia na- 
barmena dauka hainbat gertaera fisiologiko eta patologikotan, batez ere zelula eukariotoetan, non konpartimentalizazio maila handia den. Hainbat dira fusioak prozesu biologikoetan daukan garrantzia nabarmentzen duten adibide garbiak. Horien artean ditugu, hain zuzen ere, espermatozoide batek burututako obuluaren ernalketa, zelula ostalarirako patogenoen sarrera, endozitosia, organuluen biogenesia, exozitosia eta beste gertaera batzuk. Fusio erreakzio guztiek ezinbesteko prozesu bati jarraitzen diote: bi mintzen arteko kontaktua, fusio poro baten sorrera eta bi mintzen arteko fusioa $[6,10]$. Prozesu horiek hesi energetiko (aldaratze indar) handiak gainditu behar dituzte, horien artean elektrostatikoak, esterikoak eta hidratazio indarrak [11]. Sistema biologikoetan, hesi energetiko horiek fusio proteinen bidez gainditzen direla uste da, proteina horien adibide dira Snare edo Rab izeneko proteinak [6]. Proteina horien berri daukagun arren, mintza fusionatzea nola lortzen duten ulertzea da, hain zuzen, Biologia Zelularrak gaur egun daukan enigma handienetako bat. Bi mintzek fusioa aurrera eramateko mekanismo fisiko eta molekularra nolakoa den guztiz ezagutzen ez bada ere, jakina da prozesu kate baten bidez arautua dagoela. Hasteko, hesi energetikoa gainditu eta bi mintzak gerturatu behar dira; ondoren, trantsizio egitura metaegonkorrak sortzen dira, eta, amaitzeko, kanpoko hemigeruzek elkarreragin eta fusionatu behar dute [6] (1. irudia). Fusio poroa sortzea ondoriotzat daukan desegituraketa hori aurkakoak diren bi teoriaren bidez azaldu izan da; horien arabera, hasierako poroa proteikoa edo lipidikoa izan daiteke.

- Poro proteikoaren teoriaren arabera, poroa bi mintzak gurutzatzen dituen proteina batez osatua dago. Proteinak mintzekiko kontaktuguneetako lipido molekulen gainean eragin eta geruza bikoitzak ez diren beste egitura lipidiko batzuk sortzen ditu. Teoria honen arabera, egitura hauek ezin izango lirateke sortu halako proteinarik ezean [6].

- Poro lipidikoaren teoriaren arabera, proteinak daukan funtzioa poroa egonkortzea eta irekita mantentzea da; hau da, prozesua burutzeko behar den aktibazio energia jaisten du [6]. Teoria honen arabera, poroaren sorrera fase lipidikoen lege fisikoekin bat dator; izan ere, mintzaren okerdura eta mikrodomeinuen sorrera lipidoek baldintzatzen dituzte [12].

Bi gainazal hidrataturen arteko aldaratze indarren hesia errazago gaindi daiteke cis aurpegian gertatzen den kono formadun lipidoen presentziaren ondorioz, lipido horiek mintzari okerdura negatibo bat ematen baitiote. Adibidez, uste da kolesterolak (Chol) fosfatidilkolina (PC) eta fosfatidiletanolamina (PE) bidez sortutako geruza bikoitza ezegonkortu dezakeela [13-15]. Gainera, ondorioztatu da C fosfolipasaren ekintzaren ondorioz sortutako diazilglizerolak sistema liposomikoetan eranstaile eta agente fusogeniko gisa jarduten duela [6]. 


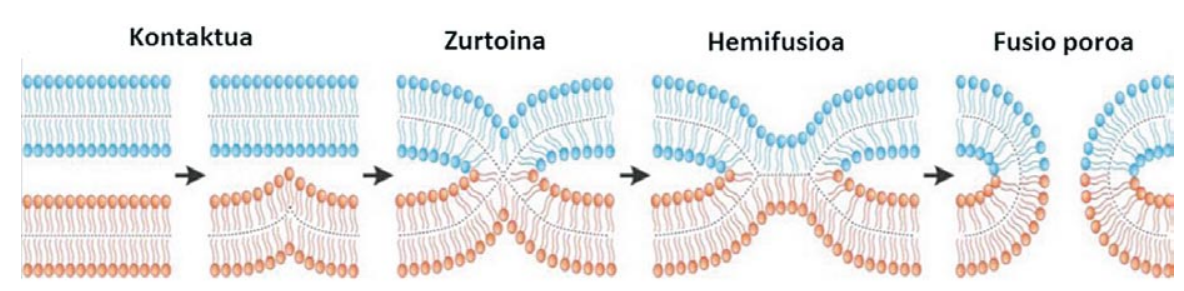

1.irudia. Zurtoinaren fusio eredua, Churchward, M.A.tik [16] moldatua.

Hainbat ikerketak erakutsi dutenaren arabera, fusioa gerta dadin, PE eta Chol mintzean egotea ezinbestekoa da; izan ere, lipido horiek mintza ezegonkortzen dute, eta, ondoren, diazilglizerolak egitura ez-lamelatuen sorkuntzan parte hartzen du $[6,17]$.

\section{HELBURUAK}

Ikerketa honen helburuak ondorengoak dira:

- Izozte-urtze zikloen bidez eragindako konposizio lipidiko (PC; esfingomielina (SM):PE:Chol (2:1:1); PC:PE:Chol (2:1:1)) eta liposoma moten (SUVak eta LUVak eta lamela ugaridun MLVak) fusioa neurtzea.

- FRET teknika bidezko fusio ikerketetan seinale optimo bat lortzeko beharrezkoa den markaketa lipidikoko portzentaje optimoa zein den ebaztea.

- Burututako izozte-urtze ziklo kopuruaren araberako fusio eraginkortasuna neurtzea.

- Fusioaren ostean sortutako egitura lipidikoen morfologia karakterizatzea.

\section{MATERIALAK ETA METODOAK}

\subsection{Materialak}

Arrautza jatorriko fosfatidilkolina, fosfatidiletanolamina, esfingomielina eta kolesterola Lipid Products (Hego Nutfield, Erresuma Batua) enpresari erositakoak dira. NBD-PE eta Rho-PE zunda fluoreszenteak Molecular Probes (Eugene, Oregon, Ameriketako Estatu Batuak) enpresak salduak izan dira. 


\subsection{Metodoak}

\subsubsection{Mintz ereduen prestaketa}

Hasteko, PC, PC:PE:Chol (2:1:1) eta SM:PE:Chol (2:1:1) lipido nahasteak nahi dugun kontzentrazioan lortzeko, beharrezkoak diren lipido bolumenak kloroformo:metanol $(2: 1, \mathrm{v} / \mathrm{v})$-ean disolbatutako lipido stock disoluzioetatik hartzen dira. Konposizio mota bakoitzeko bi populazio sortzen dira: alde batetik, fluoreszenteki markatu gabekoa, eta, bestetik, $\% 1$ NBD-PE eta \% 1 Rho-PE bidez markatutakoa. Ondoren, $\mathrm{N}_{2}$ gas fluxu baten bidez disolbatzaile organikoa lurrundu, eta lipido film lehor bat sortzen da. Disolbatzaile organikoaren hondakinak guztiz kentzeko, laginak 90 minutuz hutsean jartzen dira. MLVak sortzeko, lipido film lehorrak $\mathrm{NaCl} 150 \mathrm{mM}$, HEPES $10 \mathrm{mM}$, pH 7,4 disoluzio indargetzailearen bidez hidratatzen dira bainu (lipidoen trantsizio tenperaturaren gainetik).-bortex bidezko 3 zikloren bidez.

MLVetatik abiatuz SUVak eta LUVak sor daitezke.

- SUVei dagokienez, MLVak sonikatuz sortzen dira [18].

- LUVei dagokienez MLVak Thermobarrel Lipex Extruder (Northern Lipids Inc., Kanada) izeneko estrusio tresna baten bidez $0.1 \mu \mathrm{m}-\mathrm{ko}$ porodun polikarbonatozko Whatman filtroetatik 10 aldiz pasarazten dira [4].

\subsubsection{Fiske bidezko fosforo inorganikoaren kuantifikazioa}

Laburki azalduta, metodo kolorimetriko bat da, zeinaren bidez laginean dagoen fosfato kopurua kalkulatzen den. Era ez-zuzen batean kuantifikatzen dira besikulak; izan ere, fosfato kantitateak laginean dagoen lipido kontzentrazioarekin korrelazio bat dauka [19].

\subsubsection{Fusio entsegua}

NBD-PE \% 1ean eta Rho-PE \% 1ean txertatuak dauzkaten liposomak zunda fluoreszenterik gabeko liposomekin proportzio ezberdinetan nahastu ziren. Lehenengo, kontrol gisa, fusio aurreko balioak neurtzeko izozte-urtze ziklorik burutu gabeko mintz eredu laginen fluoreszentzia emisioa neurtu zen Aminco Bowman Series 2 (ThermoFisher Scientific, Waltham, $M A$ ) espektrofluorimetro baten bidez. NBD-PEa $465 \mathrm{~nm}$-an kitzikatu, eta haren emisioa $530 \mathrm{~nm}$-ko uhin luzeran neurtu zen, horretarako $515 \mathrm{~nm}$-ko etete filtro bat erabiliz.

Energia transferentzia bi fluoroforoen kitzikatze eta emisio espektroen gainjartzearen ondorioz gertatzen da. NBD-PE (energia emailea) $465 \mathrm{~nm}$-an kitzikatzean, bere emisio energia $530 \mathrm{~nm}$-ko uhin luzeran la- 
gatzen dio Rho-PE energia hartzaileari, eta horrek sistemaren emisioa $580 \mathrm{~nm}$-ra desplazatzen du. Beraz, bi fluoroforoak gertu daudenean, ez dugu NBD-PEren fluoreszentzia emisiorik jasotzen, haren energia RhoPEra igarotzen baita. Behin kontrolak neurtuta, fusioa gertatzeko izozte-urtze zikloak burutu ziren; minutu bat $\mathrm{N}_{2}$ likidoan (lagina izozteko) eta 15 minutu giro tenperaturan (lagina urtzeko). Azkenik, laginen bigarren neurketa bat egin zen NBD-PEren fluoreszentziak jaso duen intentsitate aldaketa neurtuz gertatutako fusioa neurtzeko. Markatutako eta ez markatutako besikulen arteko fusioa gertatzean, fluoroforoak bata bestearengandik aldendu, eta NBD-PEren fluoreszentzia intentsitateak gora egiten du. Fusioa kuantifikatzeko espektrofluorimetroan neurtutako ziklo aurreko eta ziklo osteko NBD-PE intentsitate ratioa kalkulatu zen.

\subsubsection{Fusio ostean sortutako egitura lipidikoen behatzea}

Izozte-urtze zikloak burutu ostean, sortutako egitura lipidiko berrien morfologia zehazteko helburuz, laginak mikroskopio bidez behatu ziren. Hasteko, ikuskatze putzuetan $250 \mu \mathrm{L}$ BSA $(2 \mathrm{mg} / \mathrm{ml})$ gehitu ziren gainazal finkatzaile bat sortzeko. Horretarako, BSA giro tenperaturan 30 minutuz inkubatzen utzi ostean, $\mathrm{NaCl} 150 \mathrm{mM}$, HEPES $10 \mathrm{mM}, \mathrm{pH}$ 7,4 disoluzio indargetzaile bidezko garbiketa bat egin zen. Gero, laginak 30 minutuz utzi ziren putzutxoetan, sedimentatu eta putzutxoen gainazalera itsas zitezen.

Azkenik, Nikon D-eclipse C1 (Nikon Corporation, Tokio, Japonia) mikroskopio konfokal bat erabiliz egiturak behatu ziren. Rho-PE $560 \mathrm{~nm}$-ko uhin luzeradun laser bidez kitzikatu zen, eta haren emisioa $583 \mathrm{~nm}$-an batu zen.

\section{EMAITZAK ETA EZTABAIDA}

Mintz ereduen arteko fusioan liposomek izan beharreko konposizio lipidiko eta besikula mota optimoak zeintzuk diren zehaztu nahi izan da. Horretarako, lehenengo, PC, SM:PE:Chol (2:1:1) eta PC:PE:Chol (2:1:1) konposizio lipidikodun SUV, LUV eta MLVak sortu ziren (populazio bat markatu gabea, eta bestea \% 1 Rho-PEz eta \% 1 NBD-PEz markatua). Gero, markatutako eta markatu gabeko besikulak \% 50eko proportzioan nahastu ziren. Azkenik, laginei 10 izozte-urtze ziklo eginarazi zitzaizkien, eta izozte-urtze ziklo aurreko eta ziklo osteko NBD-PE intentsitateak neurtu eta ratioak kalkulatu ziren (2. irudia).

Erabilitako lipido konposizio ezberdinak beren artean konparatuz, SM:PE:Chol (2:1:1) konposiziodun besikulen arteko fusioa izan da baxuena (2. irudia). Esan behar da ia hutsa izan dela; izan ere, lagina/kon- 
trola fluoreszentzia ratioa 1 inguruko da. Gainera, konposizio hori izanik, jokabide bera errepikatzen da erabili diren mintz eredu guztietan. Bestalde, PC eta PC:PE:Chol (2:1:1) konposiziodun besikulen arteko fusio maila handiago bat neurtzen da. Bi horiek beren artean konparatuz, bigarren kasuan fusio maila altuagoak lortzen direla ikusten da (2. irudia). Ziur aski, Chol-ek, PCren eta PEren presentzian, errazten du geruza bikoitza ezegonkortzea eta bi gainazal hidratatuen arteko aldaratzeek eragindako hesi energetikoa gainditzea. Gainera, kolesterolak domeinuak sortzea eta, hortaz, fusioa gertatzea eragin dezake. Bestalde, SM PC baino askoz zurrunagoa denez, SMen eta Chol-en artean sortzen diren domeinuak hain dira zurrunak ezen fusioa gertatzea zaildu baitezakete.

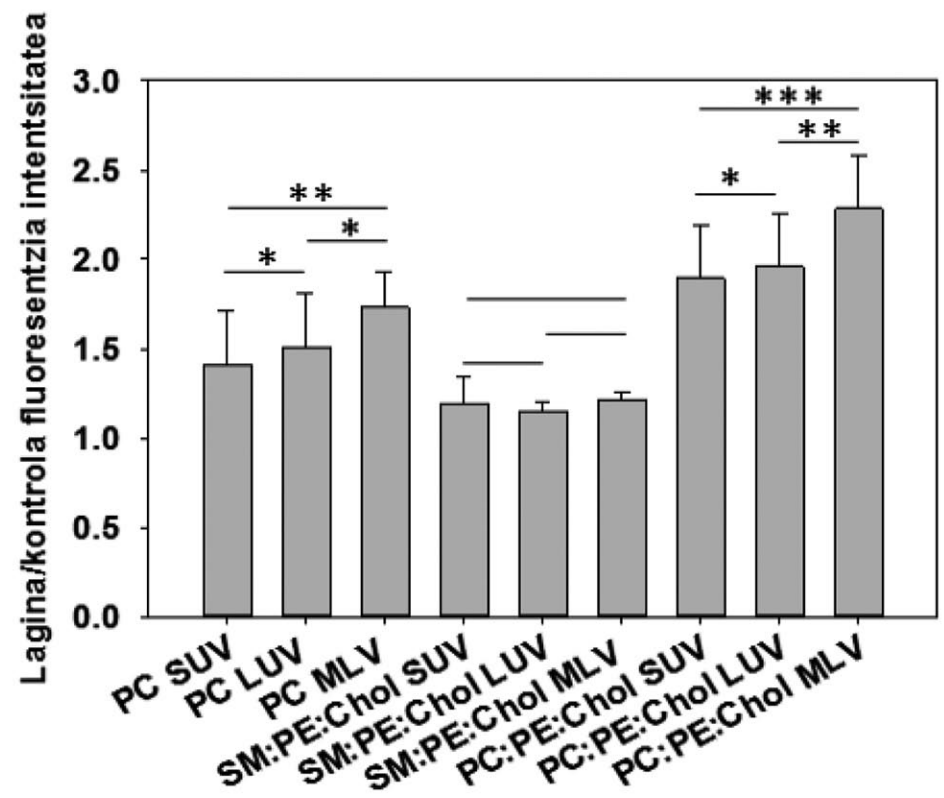

2. irudia. Mintz eredu motaren eta konposizio lipidikoaren eragina izozte-urtze ziklo bidezko fusioan markatutako eta markatu gabeko besikulak proportzio berean nahastu ostean. Amaierako kontzentrazioa: $0.05 \mathrm{mM}$ markatuak $+0.05 \mathrm{mM}$ markatu gabeak. Esperimentu bakoitza gutxienez 3 aldiz egin da. Student $\mathrm{t}$ test bidez frogatu da aldeak esanguratsuak diren.

PC eta PC:PE:Chol (2:1:1) konposizio lipidikodun mintz ereduak beren artean konparatzen baditugu, bi kasuetan gauza bera gertatzen dela ikusten dugu: fusio maila altuena MLVekin eta baxuena SUVekin neurtzen dela, hain zuzen ere. Bestalde, LUV besikulen fusioan, SUVen eta MLVen tarteko balioa neurtzen da. 
Laburbilduz fusio efizientzia honela ordena dezakegu (2. irudia):

- Konposizio lipidikoaren arabera: PC:PE:Chol $(2: 1: 1)>$ PC > SM:PE:Chol (2:1:1).

- Liposoma motaren arabera: MLV > LUV > SUV.

Entsegu honen bitartez lortutako emaitzen ostean baztertu genuen SUV besikulekin eta SM:PE:Chol (2:1:1) konposizio lipidikoarekin lan egiten jarraitzea.

Ondoren, FRET seinale optimo bat izateko erabili beharreko liposoma markatuen portzentajea zein den neurtzeko entsegua egin zen (3. irudia). Izan ere, jakina da zunda fluoreszenteak kantitate handitan erabiltzeak besikulen benetako ezaugarri fisiko-kimikoak alda ditzakeela eta horrek kalkulatutako balioen interpretazio desegoki batera eraman gaitzake.
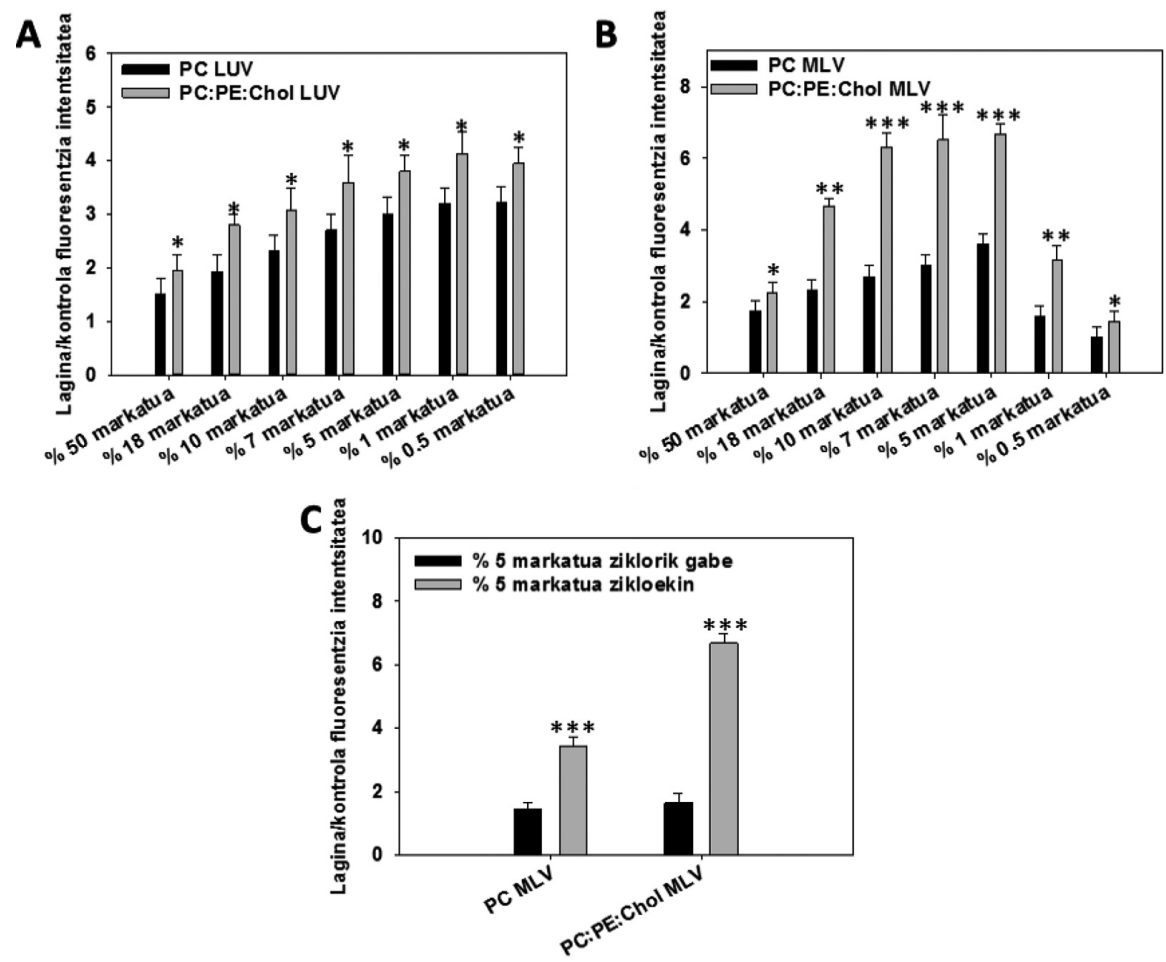

3. irudia. FRET seinale optimo bat bermatzen duen besikula markatuen portzentajearen determinazioa. LUVetan (A) eta MLVetan (B). Kontrola (C). Liposoma markatuen kontzentrazioa $0.05 \mathrm{mM}$ da kasu guztietan. Markatu gabeko liposomen kontzentrazioa: \% 50 markatuan $0.05 \mathrm{mM}$; \% 18 an $0.225 \mathrm{mM}$; \% 10ean $0.45 \mathrm{mM}$; $\%$ 7an $0.675 \mathrm{mM}$; \% 5ean $0.95 \mathrm{mM}$; \% lean 4.95mM; \% 0.5ean 9.95mM. Esperimentu bakoitza gutxienez 3 aldiz egin da. Student $t$ test bidez frogatu da aldeak esanguratsuak diren. 
Aurreko entseguan bezala, kasu honetan ere, fusio maila ziklo aurreko eta ziklo osteko fluoreszentzia balioen ratio gisa neurtu zen. 3. irudian ikusten den bezala, PC eta PC:PE:Chol (2:1:1) konposizio lipidikodun LUVekin eta MLVekin lan egin zen. 3A eta B irudian ikusten den bezala, fusio ratio altuena lortzeko erabili beharreko besikula markatuen portzentaje optimoa $\% 5$ izan da $(0.05 \mathrm{mM}$ liposoma markatu eta $0.95 \mathrm{mM}$ liposoma markatu gabe), egoera hori besikulak PC eta baita PC:PE:Chol (2:1:1) konposizio lipidikokoak direnean gertatzen da. LUVen entseguari dagokionez (3A irudia), markatutako besikulen portzentajea \% 50etik jaitsiz doan heinean, fluoreszentzia intentsitatearen ratioa gero eta handiagoa da \% 5eko liposoma markatuen baliora iritsi arte. Portzentaje horretan egonkortu egiten da, ikusten denez \% 5etik beherako balioetan ere antzeko ratio balioak lortzen baitira.

MLVei dagokienez (3B irudia), LUVen kasuen antzera, fluoreszentzia intentsitatearen ratioa handitu egiten da besikula markatuen portzentajea zenbat eta baxuagoa izan. LUVen kasuan gertatzen den bezala, $\%$ 5eko markaketan ratioaren balio maximoa lortzen da. Dena den, balio baxuagoetan fluoreszentzia intentsitatearen ratioa jaitsi egiten da. Kontuan izan behar da entsegu hauetan markatutako besikulen kontzentrazioa konstante mantentzen dela eta, hortaz, horien proportzioa jaisteko helburuz, markatu gabeko besikulen proportzioa handitzen dela. Era berean, MLVak SUVak eta LUVak baino handiagoak izanik eta, gainera, lamela bat baino gehiago edukita, lagina arreagoa da. Ondorioz, laserraren izpiak lagina guztiz zeharkatzeko zailtasunak izango ditu, eta, hortaz, espektrofluorimetroak ez dizkigu benetako FRET balioak islatuko. Laburbilduz, esan daiteke kontzentrazio altuetan arazo esperimental baten aurrean egon gaitezkeela.

Azkenik, FRET seinalearen igoera zikloek eragindakoa eta ez berezko fusioaren ondoriozkoa dela baieztatzeko, kontrol bat egin zen (3C irudia). Entsegu paralelo bat egin zen; alde batetik, \% 5 MLV markatudun lagin bati izozte-urtze zikloak eginarazi zitzaizkion, eta, bestetik, lagin bera bere horretan utzi zen zikloek iraun zuten bitartean. $3 \mathrm{C}$ irudian ikusten den bezala, izozte-urtze ziklorik eginarazi ez zitzaion laginean, ratioa 1 ingurukoa da; hau da, ez da seinale igoerarik lortzen. Hortaz, FRET seinalearen igoera izozte-urtze zikloen ondoriozko fusioak eragindakoa dela baiezta dezakegu.

Aurreko entseguetan, 10 izozte-urtze ziklo erabili izan dira. Dena den, fusio maximoa lortzeko beharrezko diren izozte-urtze ziklo kopurua kalkulatzeko entsegu bat egin zen. Esperimentu horretan, ziklo aurreko fluoreszentzia ratioaren neurketa bat eta ziklo bakoitzaren osteko neurketak egin ziren (4. irudia). Horretarako, PC:PE:Chol (2:1:1) konposizio lipidikodun LUV eta MLV markatuak erabili ziren (\% 5ean markatuak). 

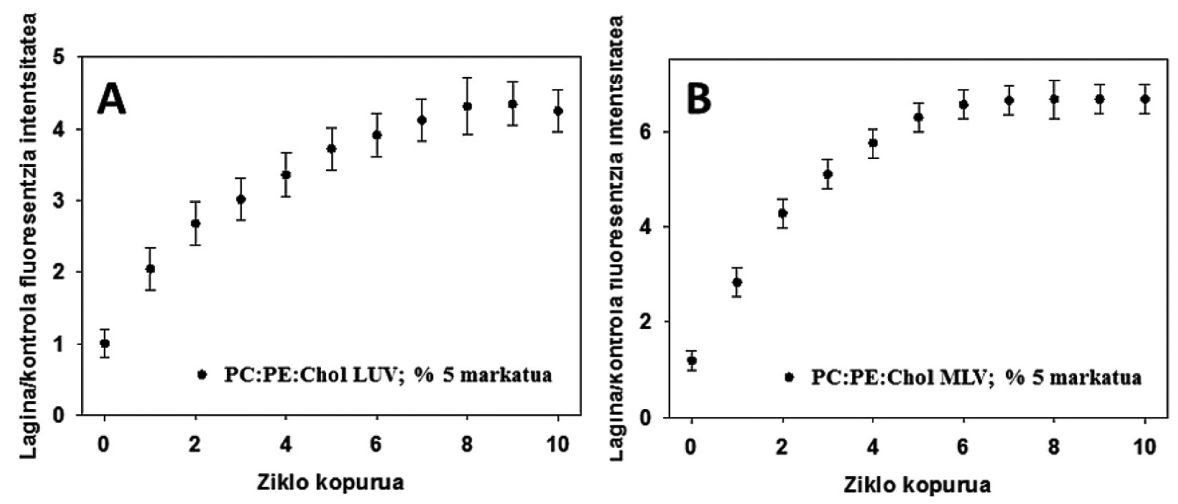

4. irudia. Fusio maximo bat lortzeko beharrezko diren izozte-urtze zikloen kopurua. \% 5 markatutako PC:PE:Chol (2:1:1) konposiziodun LUVak (A) eta \% 5 markatutako PC:PE:Chol (2:1:1) konposiziodun MLVak (B). Esperimentu bakoitza gutxienez 3 aldiz egin da.

Bi kasuetan grafikoek forma hiperboliko bat erakusten dute. Liposoma gehienak lehen zikloaren ostean fusionatzen dira, eta ondorengo ziklo bakoitzean gertatzen den fusioa txikituz doa 7-8 zikloren ostean balioak egonkortu arte, hau da, fusio maximo bat lortu arte.

Azkenik, izozte-urtze zikloen ostean sortutako egitura lipidikoek hartzen duten morfologia zehazteko helburuz, Nikon D-eclipse C1 (Nikon Corporation, Tokio, Japonia) mikroskopio konfokal baten bidez laginak behatu ziren. Ikuskatze putzuetako egitura lipidikoen Rho-PEa $560 \mathrm{~nm}$-ko uhin luzeradun laserraz kitzikatu, eta $590 \mathrm{~nm}$-ko uhin luzeran batu zen haren emisioa (5. irudia).

5. irudian ikusten den bezala, esan daiteke MLV (5A eta 5C) eta LUV (5B eta 5D) laginen ziklo osteko egiturak antzeko diametrodun besikula lipidikoak direla, 4-8 $\mu \mathrm{m}$-ko diametrodunak, hau da, GUVek izan ohi duten diametroen antzekoak. Kontuan eduki behar da LUVen tamaina $100 \mathrm{~nm}$ ingurukoa denez, izozte-urtze ziklo hauetan fusioa ez dela soilik 1:1 besikula ratioan gertatzen; hainbat LUVek bat egiten dute 40-80 aldiz diametro handiagoko egitura lipidikoak sortzeko.

Dena den, irudian ikusten den bezala, fusioa ez da era guztiz garbi batean gertatzen; izan ere, $5 \mathrm{~A}$ eta $5 \mathrm{D}$ irudietan ikusten den moduan, geruza bikoitzean erantsitako lipido multzo txiki batzuk ikusten dira. Gainera, $\mathrm{C}$ irudian ikusten den bezala lipido multzo horiek, geruza bikoitzean egoteaz gain, liposomen barnean ere ageri dira. Badirudi izozte-urtze zikloetan besikuletako batzuek beren egitura esferikoa galdu eta egitura irregularrak sortzen dituztela. Esan daiteke izozte-urtze zikloen metodoa GUVak modu 
erraz batean sortzeko metodoa izan daitekeela, nahiz eta argi utzi behar den elektroformazioa bezalako beste metodo batzuetan errendimendu handiagoa lortzen dela.
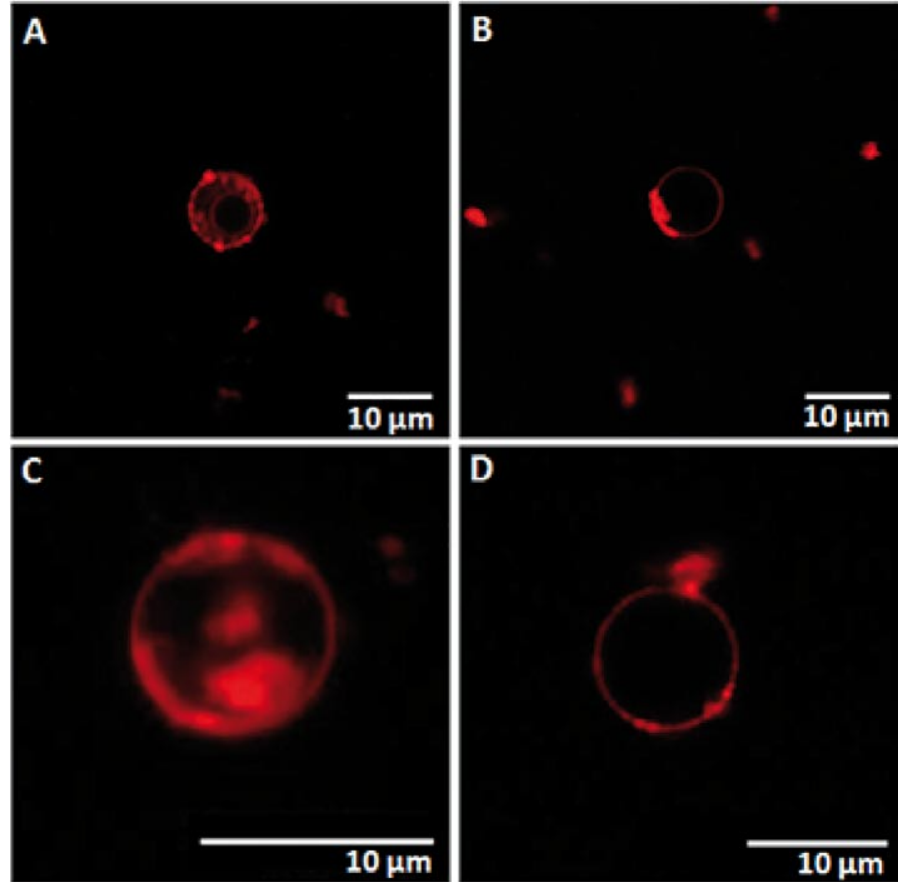

5. irudia. Izozte-urtze zikloaren ostean sortutako egitura lipidikoen mikroskopio konfokal bidezko behatzea. PC:PE:Chol (2:1:1) konposizio lipidikodun MLVen fusio osteko egiturak (A eta C). PC:PE:Chol (2:1:1) konposizio lipidikodun LUVen fusio osteko egiturak (B eta D). Esperimentu bakoitza gutxienez 3 aldiz egin da.

\section{ONDORIOAK}

Ikerketa honetako ondorio gisa esan daiteke izozte-urtze bidez lortutako fusio errendimendu altuago bat erakusten duten mintz ereduak PC:PE:Chol-ez (2:1:1) eta PCz sortutako MLVak eta LUVak direla eta hori lortzeko 7-8 ziklo burutzea beharrezkoa dela, zeinen artetik PC:PE:Chol (2:1:1) konposiziodun MLVek baitaukate fusio maila altuena. Bestalde, SUVek eta SM:PE:Chol (2:1:1) konposiziodun LUV eta MLVek ez dute ia fusiorik ematen. Gainera, FRET balio altuena lortzea ahalbidetzen duen besikula markatuen portzentaje minimoa $\% 5$ dela kalkulatu da. Azkenik, 
mikroskopio konfokal bidezko fusio osteko egituren behaketan ikusten denez, sortutako egiturek 4-8 $\mu \mathrm{m}$-ko diametroak dauzkate. Hortaz, GUVen antzeko tamainak dauzkatenez, halakoak sortzeko metodo erraz baten aurrean egon gaitezke.

Amaitzeko, komeni da esatea, besikulen arteko fusioa era artifizial batean kontrolatzeak ikerkuntzaren eta medikuntzaren esparrua zabal lezakeela. Izan ere, exosomak, mintz plasmatikozko besikula erraldoiak edo zeluletan berez agertzen diren bestelako liposomak, interesatzen zaizkigun mintz ereduekin fusionatuz, posible da haien konposizioa eraldatzea. Liposoma hibrido horiek, zelulen berezko liposomak dauzkatenez, sistema immunea errazago gaindi lezakete, eta, hortaz, farmakoak helarazteko garrantzia izan dezakete nanogarraiatzaile gisa jardunez.

\section{LABURDURAK}

SUV: Small Unilamellar Vesicles. Lamela bakarreko besikula txikiak.

LUV: $\quad$ Large Unilamellar Vesicles. Lamela bakarreko besikula handiak.

MLV: $\quad$ Multilamellar Vesicles. Lamela anitzeko besikulak.

GUV: Giant Unilamellar Vesicle. Lamela bakarreko besikula erraldoiak.

FRET: Fluorescence Resonance Energy transfer. Erresonantzia bidezko energia transferentzia.

NBD-PE: 1,2-dipalmitoyl-sn-glycero-3-phosphoethanolamine-N-(7-nitro-2-1,3benzoxadiazol-4-yl).

Rho-PE: 1,2-dioleoyl-sn-glycero-3-phosphoethanolamine-N-(lissamine rhodamine B sulfonyl).

Chol: Cholesterol. Kolesterola.

PC: $\quad$ Phosphatidylcholine. Fosfatidilkolina.

PE: $\quad$ Phosphatidylethanolamine. Fosfatidiletanolamina.

SM: $\quad$ Sphingomyelin. Esfingomielina.

BSA: Bovine Serum Albumin. Behi serumeko albumina.

HEPES: 4-(2-Hydroxyethyl)piperazine-1-ethanesulfonic acid, N-(2 Hydroxyethyl)piperazine-N'-(2-ethanesulfonic acid).

\section{ESKER ONAK}

Lan hau FEDER MINECOk (BFU 2015-66306-P) eta Eusko Jaurlaritzak (IT-849-13) emandako diru laguntzei esker gauzatu da. Bingen G. Monasterio Euskal Herriko Unibertsitatearen bekaz diharduen doktorego aurreko ikaslea da. 


\section{BIBLIOGRAFIA}

[1] BANGHAM, A. D., STANDISH, M. M., WATKINS, J. C. 1965. «Diffusion of Univalent Ions across the Lamellae of Swollen Phospholipids». Journal of Molecular Biology, 13, 238-252.

[2] VANCE D., VANCE J. E. 1996. Biochemistry of Lipids, Lipoproteins and Membranes. Elsevier, Alberta.

[3] CHAPMAN D. 1984. Physicochemical Properties of Phospholipids and Lipid-Water Systems in 'Liposome Technology'. CRC Press, Boca Ratón, Miami.

[4] MAYER, L. D., HOPE, M. J., CULLIS, P. R. 1986. «Vesicles of variable sizes produced by a rapid extrusion procedure». Biochimica et Biophysica Acta, 858, 161-168.

[5] SZOKA, F., PAPAHADJOPOULOS, D. 1980. «Comparative properties and methods of preparation of lipid vesicles (liposomes)». Annu Rev Biophys Bioeng, 9, 467-508.

[6] PALOMARES JEREZ, M. F. Búsqueda y caracterización biofísica de las regiones membranotrópicas de las proteínas estructurales del virus de la hepatitis $C$, Universidad Miguel Hernández de Elche, Instituto de Biología Molecular y Celular, 2008.

[7] NEW R. R. C. 1990. Liposomes: A Practical Approach. Oxford University Press, Oxford.

[8] BASU S. C., BASU M. 2002. Liposomes Methods and Protocols. Springer Protocols, Berlin.

[9] MERINO, S. «Aplicación de técnicas de fluorescencia microscopia de fuerza atómica al estudio de la interacción lípido-proteína en modelos de membrana», Universidad de Barcelona, Facultad de Farmacia, Departamento de Fisicoquímica, 2005.

[10] JAHN, R., GRUBMÜLLER, H. 2002. «Membrane fusion». Current opinion in cell biology, 14, 488-495.

[11] CHERNOMORDIK, L. V, KOZLOV, M. M. 2003. «Protein-lipid interplay in fusion and fission of biological membranes». Annu. Rev. Biochem., 72, 175-207.

[12] JAHN, R., SÜDHOF, T. C. 1999. «Membrane fusion and exocytosis». Annu. Rev. Biophys, 68, 863-911.

[13] SIEGEL, D. P., BANSCHBACH, J., ALFORD, D., ELLENS, H., LIS, L. J., QUINN, P. J., YEAGLE, P. L., BENTZS, J. 1989. «Physiological Levels of Diacylglycerols in Phospholipid Membranes Induce Membrane Fusion and Stabilize Inverted Phases». Biochemistry, 28, 3703-3709.

[14] ALONSO, A., M. GOÑI, F. 1999. «Structure and functional properties of diacylglycerols in membranes». Progress in Lipid Research, 38, 1-48.

[15] VILLAR, A. V, GOÑI, F. M., ALONSO, A. 2001. «Diacylglycerol effects on phosphatidylinositol-specific phospholipase $\mathrm{C}$ activity and vesicle fusion». FEBS Letters, 494, 117-120. 
[16] CHURCHWARD, M. A., COORSSEN, J. R. 2009. «Cholesterol, regulated exocytosis and the physiological fusion machine Matthew». Biochemical society, 423, 1-14.

[17] IBARGUREN, M., BOMANS, P. H. H., RUIZ-MIRAZO, K., FREDERIK, P. M., ALONSO, A., GO, F. M. 2015. «Biointerfaces Thermally-induced aggregation and fusion of protein-free lipid vesicles». Colloids and Surfaces $B, 136,545-552$.

[18] HUANG, C. 1969. «Studies on Phosphatidylcholine Vesicles. Formation and Physical Characteristics». Biochemistry, 8, 344-352.

[19] FISKE, C. H., SUBBAROW, Y. 1925. «The colorimetric determination of phosphorous». The journal of biological chemistry, 66, 375-400. 